«Keruen» scientific journal

M.O.Auezov Institute of Literature and Art

ISSN 2078-8134

Volume 2, Number 71 (2021)

https://doi.org/10.53871/2078-8134.2021.2-03

IRSTI 17.09.09

\author{
S.V. Ananyeva \\ M.O. Auezov Institute of Literature and Art \\ Almaty, Kazakshtan \\ e-mail: svananyeva@gmail.com \\ ORCID: 0000-0001-7349-1590
}

\title{
POSTMODERN VISION OF THE WORLD IN MODERN LITERATURE
}

\begin{abstract}
The leading trends in the world literary process are summarized in the article based on the analysis of modern Kazakh, Belarusian and Finnish literature, which are characterized by new approaches to the interpretation of reality, reflecting the postmodern world view. Prose writers and poets build complex spatio-temporal relationships in literary texts, when pictures of the past replace the present, complementing and concretizing what has already happened. The transformation of the structure of the work of art, the chain of incredible coincidences and repetitions, the lyrical-autobiographical nature of the narrative, the metaphorical style, mythological imagery make it possible to fancifully interweave pictures of reality and fiction.

The authors continue the experiment with the language and text, graphic design in different fonts, the inclusion of SMS messages, visuals, editing and clip series of images. A characteristic feature of the works is autobiography. The theme of family, childhood and gender policy is becoming a leading topic in modern Finnish and Belarusian literature. The literary text comes closer to the media text. Belarusian, Kazakh and Finnish literature are active participants in the world literary process. A postmodern vision of the world opens up new possibilities for creating characters of heroes and entering into dialogue thanks to new literary translations.
\end{abstract}

Keywords: discourse, modern literature, trend, tendency, postmodern, narrator, surrealism, science fiction, novel, allusions.

Introduction. The study of the modern world literary process includes the revealing of its thematic diversity, main directions of the development of national literatures, the leading discourses of poetry and prose, drama and journalism, the search for new forms of artistic expression of the author's personality and the world. The reception of national literatures as original models of thinking is of special focus in the contemporary literary process «in the conditions of development and deepening of the intercultural communication gains» (Lomidze, Megrelishvili, Modebadze, 2011: 18).

The deepening and expansion of ethnocultural and linguistic contacts is changing the language situation of the XXI century. A new bi-and poly-lingual picture of the world is formed in which ethnic identity (identity, self-identification of an individual with a certain ethnic group, ethnos, nation) includes the complicity of ethnocultural tradition.

A. Zhaksylykov characterizes the twentieth century as «the century of clashes of ideologies, deep faults and the movement of mythological matrices. The struggle of myths and ideas with great power affects the fate of modern mankind» (Zhaksylykov, 2013: 225). The narrator in modern literary criticism and his role in the work are of great interest. Researchers distinguish the author and the narrator. The author as the creator of the narrative work in prose and a fictitious character that is not identical with the author. A special, «key role in national literature is played by the narrator-author» (Ananyeva, Tattimbetova, Zhaksylykov, 2016: 26). Thanks to his active position in the literary process, the modern era, time and its rhythm are reflected in his works. 
Each author is focused on the «ideal reader». This topic is the main focus of the modern Belarusian prose writer A. Badak in "The Ideal Reader». "The vast majority of writers dream of their mass readers, and only a few dream of an ideal reader, realizing that there are not many more ideal (this means talented) than talented writers» (Badak, 2016: 86).

Methods. The main method of analysis is a literary study of both individual works of prominent representatives of Kazakh, Belarusian and Finnish literatures, as well as the work of writers in general.

Results. Amalgamation of genres and styles, fragmentary plot, deconstruction of the text, change of stylistic and genre codes are increasing in modern prose. The written heritage and oral folklore largely determine the poetological originality of modern Kazakh literature. The eternal problems of spiritual and moral values, world ethics, dialogue and cooperation are artistically embodied in the works of Kazakh prose writers, who often rely on myths, legends, and traditions in their narrative. Magical realism gives artistic texts a unique identity.

The leading trends of the modern world literary process have been determined in the following sequence: humanistic orientation of contemporary literature; reflection of the spiritual phenomenon of being and return to national «origins»; artistic cosmogenesis as a combination of different virtual realities at junction of personal / ontological consciousness; anthropological concept of personality and ontological model of being; restoration of genre forms, evolution and their transformation; the formation of a new genre thinking.

It was revealed that modern literature of Finland is polylingual and develops intensively in different genre manifestations. Artistic works are published in Finnish, Swedish and Saami (Lapp) languages. Its central theme is the personal life of the hero-citizen, an inherent feature of which is an innate sense of humor, helping him to look at the problems of the surrounding reality and solve them, based on the situation. Novel works are represented by works of K. Chilman, writing sharply, maliciously and mocking decadent moods in the Swedish-speaking society of the country, autobiographical stories of H. Tikkanen, satirical pamphlets and stories by J. Bargum. The winner of the Runeberg Prize for the best work in Finnish or Swedish in 2005 was the Finnish writer of Russian origin Z. Linden (Turku) for the novel «Waiting for an earthquake». A significant event in the literary life of Finland was her first collection of short stories «Colonel and Synthesizer», for which the author received the award of the Society of Swedish-Language Literature of Finland.

The combination of the experiment with «sharp realism» in the artistic works in depicting the characters of the actors against the backdrop of supernatural events has become one of the newest trends in the development of modern literature in Finland. Gothic romance of horrors, ghosts in student hostels, city apartments and ferries surrounded by water are not so rare elements of narrative structures. The novel «The Obsession of Martina Dagger» by the poet, prose writer, translator Henriki Ringbum is compared with a Helsinki suite woven from love for the city and its environs. The main character of the narrative is a young talented girl, educated, in love with her profession and obsessed with it. The language of the character of the novel is complex and the language of the work is poetic. Behind the façade of reality there are amazing visions that eventually destroy her life.

The theme of the Great Patriotic War continues to occupy a special place in the contemporary literature of Belarus. In the year of the 75th anniversary of the beginning of the Great Patriotic War, the Zvyazda Publishing House and the newspaper Zvyazda launched an action to create the museum of Ales Adamovich. The project was launched on the day of the memory of the famous Belarusian writer, whose «Khatyn story» was translated in English and French (in French - «Go and See») and was included in the short list of the best creations of the XX century. The reader's attention was attracted by the novels of N. Cherginets «Operation Blood» (the novel is devoted to how during the Great Patriotic War the Nazis created a children's concentration camp and took away the blood from children, conducted other medical experiments on children) and Ales Savitsky «Obol» (the name of the settlement where the youth underground anti-fascist organization worked in the Great Patriotic War). 
Discussion. The Finnish literature in the Sami language is original and takes inspirations from folklore, story-legends about miracles, supernatural beings. But the most important component of modern literature in Finland is the part that is written in Finnish, for instance as in the works of M. Jotuni, H. Vuolijoki and J. Turk. The leading tendencies of Finnish literature of the first 15 years of the XXI century are the disclosure of the inner world of the contemporary, the emotional experiences of the characters, and the openness of young writers to the world.

Black jackdaws as one of the archetypes of the novel-debut of Stefan Neuman's «Anna Online», revealing the relationship between young people, modern students, send the reader to the works of Edgar Poe and Agatha Christie («A pocket full of rye») with the motives of overwhelming fear. The real world and the surreal world, a world inexplicable in the images of ancient folklore characters, is a characteristic feature of the narrative strategies of literature for adolescents created by $\mathrm{H}$. Anderson and M. Turchaninoff. The main features of Finnish Swedish literature, which traditionally distinguish it from the literature of Sweden and Finland, are an experiment game, a lack of love and blood (very rarely the authors write about murders, love, erotica), another life beyond reality (texts that combine experiment with realism).

Lena Lehtolainen, the author of a series of detectives about the investigation of the main character Maria Kallio of mysterious crimes is called the queen of the detective genre, Finnish Agatha Christie, which are translated into 20 world languages.

The ecological theme of childhood and family; the theme of alienation and loneliness and the search for oneself in a modern multicultural society, existential themes and problems, the moral crisis of society have become the main themes and problems of the world literary process in the 21 st century. Neoclassical forms of poetic thinking include philosophical search, ironic perception of reality, a sense of the absurdity of what is happening, mythological imagery. Female prose and poetry are actively represented.

The polygenre synthesis in the conditions of bilingualism and multilingualism, the dialogue of cultures in Finnish literature is implemented in the works of immigrant writers Z. Linden, A. Salmely and others, whose «voices in general literary polyphony become more and more noticeable» (Paavolainen, 2011: 9). Mathias Rosenlund reveals the experience of pluralism in Finnish-Swedish literature («Karma» by Marianne Baklen) and multicultural reality (the novel about young Muslim women in Helsinki by Johanna Holmström «The Angels of Asphalt»), writes about xenophobia and cultural diversity of modern Europe (Rosenlund, 2014:12).

Modern literature is analyzed «as a way of survival in the world of chaos, a risk zone and / or the experience of freedom», the «trans-avant-garde paradigm in modern literature, the deficiency of meanings» (Ermolin, 2015: 124) is observed. It is interesting to compare it to the fact that «Bulgarian postmodernism developed and reached its climax in the 90s of the XX century» (Antov, 2010: 9).

In the prose of Belarusian writers - lessons of kindness and compassion, humanity and wisdom, high moral purity. Memory - counterpoint goes through prose and lyrical poetry of Belarusian authors. Particularly important in terms of comparative studies, literary connections and literary translation, the main mission of which is to acquaint readers with world literature, round tables at Zvyazda Publishing House and Belarusian editions of recent years. In the modern literary space of Belarus, the problems of literary criticism and literary translation are actively discussed.

Multimedia tools and technologies largely determine «the nature and direction of modern mass communications, their impact affects the processes of preservation and translation of cultural values» [Eliner, 2010: 302], on the prospects of literary development, which illustrates the anthology of Finnish children's literature «Good Neighbors». Compositional material in the book is arranged in such a way that the portrait drawings of the authors made in the technique of "graffiti» are given before the prosaic texts and a small questionnaire including the writer's name, age, creativity and last column is the most remarkable «In childhood I wanted to become ...». The anthology «Good Neighbors» is illustrated with drawings, playful tasks for children: «Write a song about the room for those who live in this room». Or: "Objects are dreaming and dream. Write about what the wardrobe dreamed last night. What does the floor lamp dream about? What 
nightmare did the fridge dream? In the old chest of drawers there are five boxes and a hiding-place - what do they dream about?» (Good Neighbors, 2011: 42).

Conclusion. National literatures in the 21 st century accumulate in their development the best achievements of the world artistic culture. The literature of the turn of the century is reaching a new level of understanding of the reality reflected in fiction, which determines the range of the main issues of the textbook: the revival of realistic traditions in the narrative, the movement from modernism to postmodernism, the complication of the plot-compositional structure of texts, active development of surreal and fantastic motifs, mythological figurativeness, metaphorical style, rapprochement of an artistic text with a media text.

Modern Belarusian literature continues the development of traditions laid down in the Soviet period. Its uniqueness lies in the fact that in the literary process there is no mass literature, tabloid. Traditions of heroic and patriotic literature come from V. Bykov, adventure literature, and detective stories from V. Korotkevich. The winner of the Nobel Prize in 2015 S. Alexievich brings the narrative of the theme of the Chernobyl tragedy and the Afghan war to a new level. The formation of Belarusian identity is taking place through fiction. The contemporary epoch, time and its rhythm are reflected in the work of contemporary Belarusian authors. Fiction is the most important factor in the humanitarian cooperation of different countries. An article by S. Ananyeva and A. Karlyukevich is devoted to the analysis of Kazakh-Belarusian literary relations, in which, according to the authors, the main trend is «the process of building a bridge of friendship between our countries» (Ananyeva, Karlyukevich, 2015: 141).

Modern Belarusian poetry is thematically diverse. Modern poets write about the meaning of life, the beauty and viciousness of human relations, the unprotected nature, the continuity of good and the multifaceted nature of evil, striving to contribute to the literature. The aching pain of memory dictates nostalgic motives to the poets who left their homeland. What is happening in modern Belarusian literature? What are the main trends and directions of its development? Who of the young poets and writers drew attention to their works? These and many other questions are answered by Y. Sapozhkov in his book «Between Spirit and Word». The book includes literarycritical articles, reviews, essays on new prose works and collections of poems by Belarusian authors, reviews of poetic collections of the magazine «Neman», reflections on the problems of literary translation, interviews with well-known foreign writers and much more. Otherwise, the book by Yu. Sapozhkov «Between Spirit and Word» could be called the threshold of audibility, since the soul «also has a threshold of audibility - surrounding life, own thoughts and experiences» (Sapozhkov, 2012: 5).

Modern literature in Finland is polylingual and is developing in Finnish, Swedish and Sami languages. Its leading trends are the disclosure of the inner world of a contemporary resident of the province, the emotional experiences of the characters, the theme of terror and violence against a person, nationalism, a high level of understanding of history. A special phenomenon - is the literature of immigrants. Modern drama dominates over the classics. Young poets of the high-tech generation are experimenting with poetic language and poetic text, questioning many poetic concepts of the era of modernism, and apply not only different computer programs and digital materials, but also the technique of fine art - the technique of «found object», demonstrating multimedia technologies in the perspective of literary development.

In modern Kazakh literature there is a comprehension of the new reality, history and critical historical moments of the turn of the century. The work of the major masters of the word has been widely recognized in the USA, Russia, Canada and Germany.

In A. Kekilbaev's short story «Ballad of Forgotten Years», the author's chronotope and characters can coincide, embodied in the structure of the work; or pictures of the past, emerging in the memory of the heroes, explain the events occurring in the present, as witnessed by the authornarrator.

The motive of unconsciousness is adjacent to the theme of loneliness: captives are alone, a tall mound is alone, like a sharp tip of a spear. The theme of loneliness is complemented by the spatial characteristics of the smooth and endless steppe. Spatial frames expand when describing an 
environment that is blurry in a midday haze. The phantom, unsteadiness of what is happening cannot soften the picture of real life.

The ballad genre, indicated in the title of the story, allows the author to alternate the pictures of battles, the excited voice of the narrator and unusual direct speech of the characters. Warrior Zhonut decided to stand up for his people: «How should his people now live in the world, driven by enemies into the bitter sands? Indeed, all his pride is the light-footed Turkmen argamak, and all his joy and honor are the purity of his daughters. And now all this has been taken away, all this has been abused, and how can you look into the eyes of your children? No! All of this must be set to a limit» (Kekilbaev, 2005: 53).

In A. Zhaksylykov's novel «Dreams of the Cursed», various characters act: the spirit of dreams, woman-light, the highest woman cloud, a little boy with the eyes of a frightened gazelle; shimmering figures that have been watching people for centuries and pushing events, people, good and evil together to see what is behind it. The symbolic polyphony of images-metaphors in the works of A. Zhaksylykov is diverse. The image of the steppes of the Golden Age, beautiful, generous and inexhaustibly rich, is the central image-symbol of the texts of A. Zhaksylykov. The steppe is remembered in the image of a running, calling and screaming woman. «Fast clouds in the sky, shadows floating on the ground, brown islands of rock massifs, and between them silver feathery straits, long waves of grass running under the wind» (Zhaksylykov, 2006: 175).

A tough medieval warrior gradually looks out of the dusty mirror opening, and a jagged cliff, the building of the ecumenical assembly, grows out of the «circling darkness». It flowed into a different projection and «slowly flowed into another time a muddy sky, the shadows of cave and forest birds hovered». The dream world with mythological images, at times, turns out to be more real than reality, recreated by the modern Kazakh prose writer, convinced that gradually «the mythological layer has gone into the human subconscious, in his memory, the doctrines of world religions and the ideology of socio-political teachings have come to the fore. However, be that as it may, in their depths they bear traces of ancient myths. World literature carries these traces, and mythological paradigmatics are often paradoxical» (Zhaksylykov, 2013: 217).

The leading trends in the global literary process are summarized in the article on the example of the development of modern Kazakh, Belarusian and Finnish literature, which are characterized by new approaches to the interpretation of reality, reflecting the postmodern world view. Magical realism and artistic bilingualism are characteristic features of national literatures selected as the object of scientific research in this article.

\author{
С.В. Ананьева \\ М.О.Әуезов ат. Әдебиет және өнер институты \\ Алматы, Қазақстан \\ e-mail: svananyeva@gmail.com
}

\title{
КАЗІРГІ ӘДЕБИЕТТЕГІ ӘЛЕМГЕ ДЕГЕН ПОСТМОДЕРНИСТІК КӨЗКАРАС
}

Аңдатпа. Бұл мақалада қазақ, беларусь және фин әдебиеттерінің үлгісімен әлемдік әдеби үдерістің әлемге деген постмодернистік көзқарасын көрсететін болмысты түсіндірудің жаңа тәсілдерін қамтитын жетекші үрдістер жинақталған. Прозаиктер мен ақындар көркем мәтіндерінде болған нәрсені толықтыра, нақтылай отырып, өткен күннің суреттерін осы шаққа алмастырып, күрделі кеңістікті-уақыттық қарым-қатынасты құрайды. Көркем шығарманың құрылымының трансформациялануы, нанғысыз сәйкестіктер мен қайталаулар тізбегі, баяндаудың лирикалық-автобиографиялық сипаты, метафоралық стиль, мифологиялық бейнелілік - ақиқат суреттері мен көркем қиялды ғажайып үйлестіруге мүмкіндік береді.

Авторлар тіл мен мәтін, әртүрлі шрифтер енгізілген графикалық рәсімдеу, smsхабарлама, бірқатар визуалды, монтаждық-бейне суреттермен эксперимент жасауды жалғастыруда. Шығармаларға тән сипат ол - автобиографиялық. Отбасы, балалық және 
гендерлік саясат тақырыптары қазіргі заманғы фин және беларусь әдебиеттерінде жетекші тақырыпқа айналуда. Көркем мәтін медиамәтінмен ұштасып келеді. Жаңа көркем аудармалардың арқасында әлемге деген постмодернистік көзқарас кейіпкерлердің мінезқұлқын жасауда, диалогқа түсуде жаңа мүмкіндіктерді ашады.

Кілттік сөздер: дискурс, қазіргі әдебиет, тренд, үрдіс, постмодерн, автор-баяндаушы, сюрреализм, фантастика, роман, аллюзия.

\author{
S.V. Ananyeva \\ M.O. Auezov Institute of Literature and Art \\ Almaty, Kazakshtan \\ e-mail: svananyeva@gmail.com
}

\title{
ПОСТМОДЕРНИСТКОЕ ВИДЕНИЕ МИРА В СОВРЕМЕННОЙ ЛИТЕРАТУРЕ
}

\begin{abstract}
. Ведущие тенденции мирового литературного процесса обобщаются в статье на примере современной казахской, белорусской и финской литератур, для которых характерны новые подходы к интерпретации действительности, отражающие постмодернистское видение мира. Прозаики и поэты выстраивают сложные пространственно-временные отношения в художественных текстах, когда картины прошлого сменяют настоящее, дополняя и конкретизируя уже свершившееся. Трансформация структуры художественного произведения, цепь невероятных совпадений и повторений, лирико-автобиографический характер повествования, метафорический стиль, мифологическая образность позволяют причудливо переплетать картины реальности и художественного вымысла.

Авторы продолжают эксперимент с языком и текстом, графическим оформлением разными шрифтами, включением sms-сообщений, визуального, монтажно-клипового ряда изображений. Характерной чертой произведений является автобиографизм. Тема семьи, детства и гендерной политики становится ведущей в современной финской и белорусской литературах. Художественный текст сближается с медиатекстом. Белорусская, казахская и финская литературы являются активными участниками мирового литературного процесса. Постмодернистское видение мира раскрывает новые возможности для создания характеров героев и вступления в диалог, благодаря новым художественным переводам.
\end{abstract}

Ключевые слова: дискурс, современная литература, тренд, тенденция, постмодерн, автор-повествователь, сюрреализм, фантастика, роман, аллюзии.

\section{Information about authors:}

S.V. Ananyeva, M.O. Auezov Institute of Literature and Art, Almaty, Kazakshtan. e-mail: svananyeva@gmail.com. ORCID iD: 0000-0001-7349-1590. Scopus iD: 57191191040

\section{REFERENCES}

[1] Ananyeva S., Tattimbetova K., Zhaksylykov A. (2016). The author's self-reflection in narratology of I.P. Shegolikhin. Journal of Language and Literature (Scopus). 7(3): 26-32 (eng.).

[2] Ananyeva S.V., Karlyukevich A. (2015). Kazakh-Belarusian Literary Relations at the Present Stage. Vestnik of Kokshetau State University Sh. Ualikhanov. A philological series. 3: 133-141 (rus.).

[3] Antov P. (2010). Poetry of the 1990s: in Bulgarian and in postmodern manner. Context. Genesis. Specifics. T.3. Plovdiv: Zhanet (bulg.).

[4] Badak A. (2016). The Ideal Reader. Prostor. 11: 84-97 (rus.).

[5] Good neighbors. Anthology. Stories and novels of Finnish writers (2011). St. Petersburg: Children's time (rus.).

[6] Zhaksylykov A. (2006). Dreams of the Damned. Almaty: Almaty Publishing House (rus.).

[7] Zhaksylykov A. (2013). The Work of the Writer and the Creative Process. Almaty: Казак университетi (rus.).

[8] Eliner I.G. (2010). Development of multimedia culture in the information society. St. Petersburg (rus.).

[9] Ermolin E. (2015). Mediums of timelessness: Literature in the postmodern era, or Transavangard. Moscow: Time (rus.).

[10] Кекилбаев А. (2005). Kekilbayev А. (2005). Ballads of the Forgotten Years. Простор. 11: 42-105 (rus.).

[11] Lomidze G., Megrelishvili T., Modebadze I. (2011). Fateful biographies Tbilisi: Mtsigiobari (rus.).

[12] Paavolainen N. (2011). About Finnish prose. Modern literature of Finland - wealth of votes (5-11). Helsinki, Finland: Ministry of Foreign Affairs (rus.). 
[13] Rosenlund M. (2014). The Wealth of Two Cultures, Finland reads. Helsinki: Ministry of Foreign Affairs (rus.).

[14] Sapozhkov Yu. (2012). Between spirit and word. Minsk: Literature and Art (rus.).

[15] Suvorov M.N. (2010) New trends in Yemeni prose in the 1990s - 2000s. Messenger of Saint-Petersbudg University. Phylology.

East studies. Journalizm (Russian Science Citation Index). 9(2): 179-187 (rus.).

\section{ӘДЕБИЕТ}

[1] Ананьева С., Тәттімбетова Қ., Жақсылықов А. И.П. Щеголихин нарратологиясындағы автор авторефлексиясы. Тіл және әдебиет журналы (Скопус), 2016. - Том 7, 3 - 26-32 б. (ағыл.).

[2] Ананьева С.В., Карлюкевич А.Н. Қазіргі кезеңдегі қазақ-беларусь әдеби қатынастары // Ш.Уәлиханов ат. Көкшетау мемлекеттік университетінің Хабаршысы. Филология сериясы. - 2015. - №3 - 133-141 б. (орыс.).

[3] Антов П. 1990 ж. поэзия: Болгар әдебиеті және постмодернизм. Болгар постмодернизмі. Контекст. Генезис. Ерекшелік. - Пловдив: Жанет, 2010 (болг.).

[4] Бадак А. Тамаша оқырман. - Простор, 2016. - №11. - 84-97 б. (орыс.).

[5] Қайырымды көршілер. Антология. Фин жазушыларының әңгімелері мен повестері- Санкт-Петербург: Детское время, 2011 (орыс.).

[6] Eliner I.G. Ақпараттық қоғамда мультимедиялық мәдениетті дамыту. - Санкт-Петербург, 2010 (орыс.).

[7] Ермолин Е. Уақытсыз медиум. Постмодернистік кезеңдегі медиум немесе трансавангард. - Мәскеу: Время, 2015 (орыс.).

[8] Ломидзе Г., Мегрешвили Т., Модебадзе И. Тағдырлы өмірбаяндар. - Тбилиси: Мцигиобари, 2011 (орыс).

[9] Жаксылықов А. Малғұндардың түсі. - Алматы: Алматы баспа үйі, 2006. (орыс.).

[10] Жаксылықов А. Жазушы еңбегі және шығармашылық үдеріс. - Алматы: Қазақ университеті, 2013 (орыс.).

[11] Кекилбаев А. Ұмыт жылдар балладасы. - Простор, 2005. - №11. - 42-105 б. (орыс.).

[12] Пааволайнен Н. Фин прозасы туралы. Финляндияның қазіргі әдебиеті - дауыс байлығы. - Хельсинки, Финляндия: Ішкі істер министрлігі, 2011. - 5-11 б.

[13] Розенлунд М. Екі мәдениет байлығы. Финляндия оқиды (12-13). - Хельсинки, Финляндия: Ішкі істер министрлігі, 2014. $-12-13$ б.

[14] Сапожков Ю. Рух пен сөз арасында. - Минск: Літаратура і Мастацтва, 2012. (орыс.).

[15] Суворов М.Н. 1900-2000-жж. йемен прозасындағы хат жазудың жаңа әдеті.- Санкт-Петербург университетінің Хабаршысы. Филология. Шығыстану. Журналистика, 2010. (РИНЦ). - Серия 9. Шығ. 2. - 179-187 б. (орыс.).

\section{ЛИТЕРАТУРА}

[1] Ananyeva S., Tattimbetova K., Zhaksylykov A. The author's self-reflection in narratology of I.P. Shegolikhin. Journal of Language and Literature (Scopus), 2016. - Vol. 7, 3. - C. 26-32 (eng.).

[2] Ананьева С.В., Карлюкевич А.Н. Казахско-белорусские литературные отношения на современном этапе // Вестник Кокшетауского государственного университета им. Ш. Валиханова. Серия филологическая, 2015. - T. 3. - C. 133-141 (rus.).

[3] Антов П. Поезията на 1990-те: Българско и постмодерно. Българският постмодернизьм. Контекст. Генезис. Специфика. Пловдив: Жанет, 2010 (bulg.).

[4] Бадак А. Идеальный читатель. - Простор. - Т. 11. - С. 84-97 (rus.).

[5] Добрые соседи. Антология. Рассказы и повести финских писателей - Санкт-Петербург: Детское время, 2011 (рус.).

[6] Eliner I.G. Development of multimedia culture in the information society. - St. Petersburg, 2010 (rus.).

[7] Ермолин Е. Mediums of timelessness: Literature in the postmodern era, or Transavangard. - Moscow: Time, 2015 (rus.).

[8] Ломидзе Г., Мегрешвили Т., Модебадзе И. Судьбоносные биографии. - Тбилиси: Мцигиобари, 2011 (рус).

[9] Жаксылыков А. Сны окаянных. - Алматы: Алматинский издательский дом, 2006 (рус.).

[10] Жаксылыков А. Труд писателя и творческий процесс. - Алматы: Казак университеті, 2013 (рус.).

[11] Кекилбаев А. Баллада забытых лет. - Простор, 2005. - Т.11. - С. $42-105$ (рус.).

[12] Пааволайнен Н. О финской прозе. Современная литература Финляндии - богатство голосов. - Хельсинки, Финляндия: Министерство иностранных дел, 2011. - С.5-11.

[13] Розенлунд М. Богатство двух культур. Финляндия читает. Хельсинки, Финляндия: Министерство иностранных дел, 2014. - C. 12-13.

[14] Сапожков Ю. Меж духом и словом. - Минск: Літаратура і Мастацтва, 2012 (рус.).

[15] Суворов М.Н. Новые манеры письма в йеменской прозе 1900-2000-х годов. // Вестник Санкт-Петербургского университета. Филология. Востоковедение. Журналистика (РИНЦ), 2010. - Серия 9. Выпуск 2. - С. 179-187 (рус.). 